\title{
New insights into the plumbing system of Santorini using helium and carbon isotopes
}

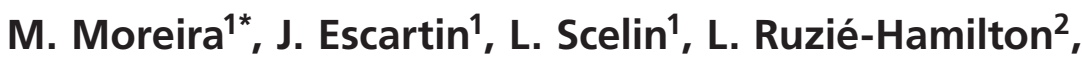 \\ P. Nomikou ${ }^{3}$, C. Mével ${ }^{1}$, M. Andreani ${ }^{4}$
}

\begin{abstract}
OPEN $(1)$ ACCES
Abstract

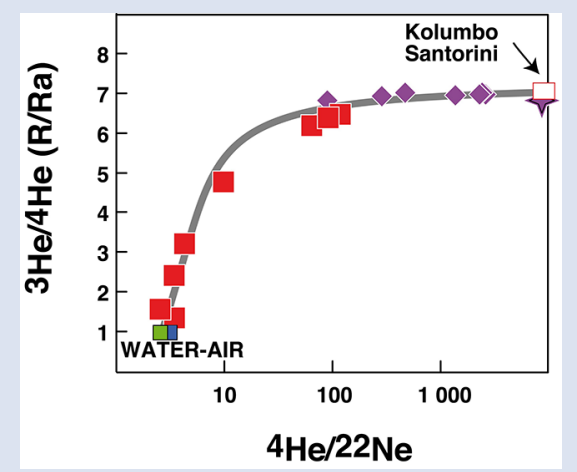

doi: 10.7185/geochemlet.1914

We have analysed $\mathrm{He}, \mathrm{Ne}$ and $\mathrm{CO}_{2}$ concentrations and isotopic ratios in seawater samples collected using a ROV above hydrothermal fields and in $\mathrm{CO}_{2}$-accumulating pools within Santorini caldera (Greece). Our results provide new insights on the plumbing and magmatic sources of this volcano, which is critical to understand and better predict its volcanic eruptions, and its relationships to nearby volcanic systems. The ${ }^{3} \mathrm{He} /{ }^{4} \mathrm{He}$ ratio is as high as 6.54 times the atmospheric ratio, and significantly higher than any other samples from Santorini, including the active eruptive centre of Nea Kameni ( $3.6 \mathrm{Ra})$. The ${ }^{3} \mathrm{He} /{ }^{4} \mathrm{He}$ ratio, corrected for atmospheric helium dissolved in seawater is $\sim 7 \mathrm{Ra}$, a value similar to that measured at the nearby Kolumbo submarine volcano crater. The fluids display typical mantle signatures never recorded before in the active centres of the island of Santorini, in which fluids and gases are contaminated at shallow depths. The helium isotopic signature suggests that the source of volatiles for these two volcanoes is similar to the MORB source instead of being the subcontinental lithospheric mantle as suggested previously.
\end{abstract}

Received 7 September 2018 | Accepted 2 April 2019 | Published 20 May 2019

\section{Introduction}

Santorini is one of the most dangerous active volcanoes on Earth, and understanding its dynamics and evolution is fundamental to constrain its degassing history and associated plumbing structure. Santorini is located in the central part of the South Aegean volcanic arc, which extends $500 \mathrm{~km}$ from the western Saronikos Gulf up to Nisyros-Kos in the east (Fig. 1). This arc results from the subduction of the remnant ocean crust of the African plate under the Aegean microplate. The last caldera-forming eruption, the famous Minoan eruption 1627 BC (Friedrich et al., 2006), was followed by several eruptions building the Palea and Nea Kameni islands within the centre of Santorini caldera (Nomikou et al., 2014). Since the last volcanic eruption in 1950, a magmatic event with no surface expression occurred between 2011 and 2012. The seismic activity and surface deformation have been attributed to a $\sim 4$ $\mathrm{km}$ deep magmatic intrusion (Parks et al., 2015). This subsurface magmatic event is supported by prior studies (Parks et al., 2013; Rizzo et al., 2015) that have shown C and He isotopic signals during this unrest period consistent with magmatic intrusion into the shallow plumbing system.

Earlier submarine explorations of the caldera seafloor identified several hydrothermal fields at depths of up to
350 mbsl (Sigurdsson et al., 2006; Nomikou et al., 2013) (Fig. 1). Among the different sites, they observed a vent field in the north of the caldera (Caldera Hydrothermal Field), extending over $200 \times 300 \mathrm{~m}^{2}$, with hundreds of mounds of variable size, $\sim 0.1$ to several $\mathrm{m}$ in diameter, and raising up to $\sim 2 \mathrm{~m}$ above the surrounding sedimented seafloor (Fig. 1). This hydrothermal field aligns with the so-called Kolumbo line, which represents a tectonic structure in the NE favouring the transport of magmas from depths, similar to the Kameni line in the SW of the caldera. The Kolumbo line extends to the NE to the Kolumbo submarine volcano, which is the largest of 25 submarine volcanic cones sited along this fault and is located $\sim 7 \mathrm{~km}$ of Santorini (Nomikou et al., 2012). Trace elements and radiogenic isotopes have shown significant differences suggesting a different petrogenesis and a different mantle source between those two volcanoes (Klaver et al., 2016), although, based on helium isotopes, Rizzo et al. (2016) suggest that the two volcanoes share the same mantle source but a different plumbing.

The $\sim 350$ m deep hydrothermal field along the NE edge of the Santorini caldera was studied in 2012 and immediately after the inflation event observed between 2011 and 2012. The Caldera 2012 cruise deployed the remotely operated vehicle (ROV) Max Rover, the submersible Thetis (both from HCMR,

\footnotetext{
1. Université de Paris, Institut de physique du globe de Paris, CNRS, F-75005 Paris, France

2. SEES- The University of Manchester, United Kingdom

3. Faculty of Geology and Geoenvironment, National and Kapodistrian University of Athens, Panepistimioupoli, Zographou, Greece

4. Laboratoire de Géologie de Lyon, UMR 5276, ENS et Université Lyon 1, France

Corresponding author (email: moreira@ipgp.fr)
} 


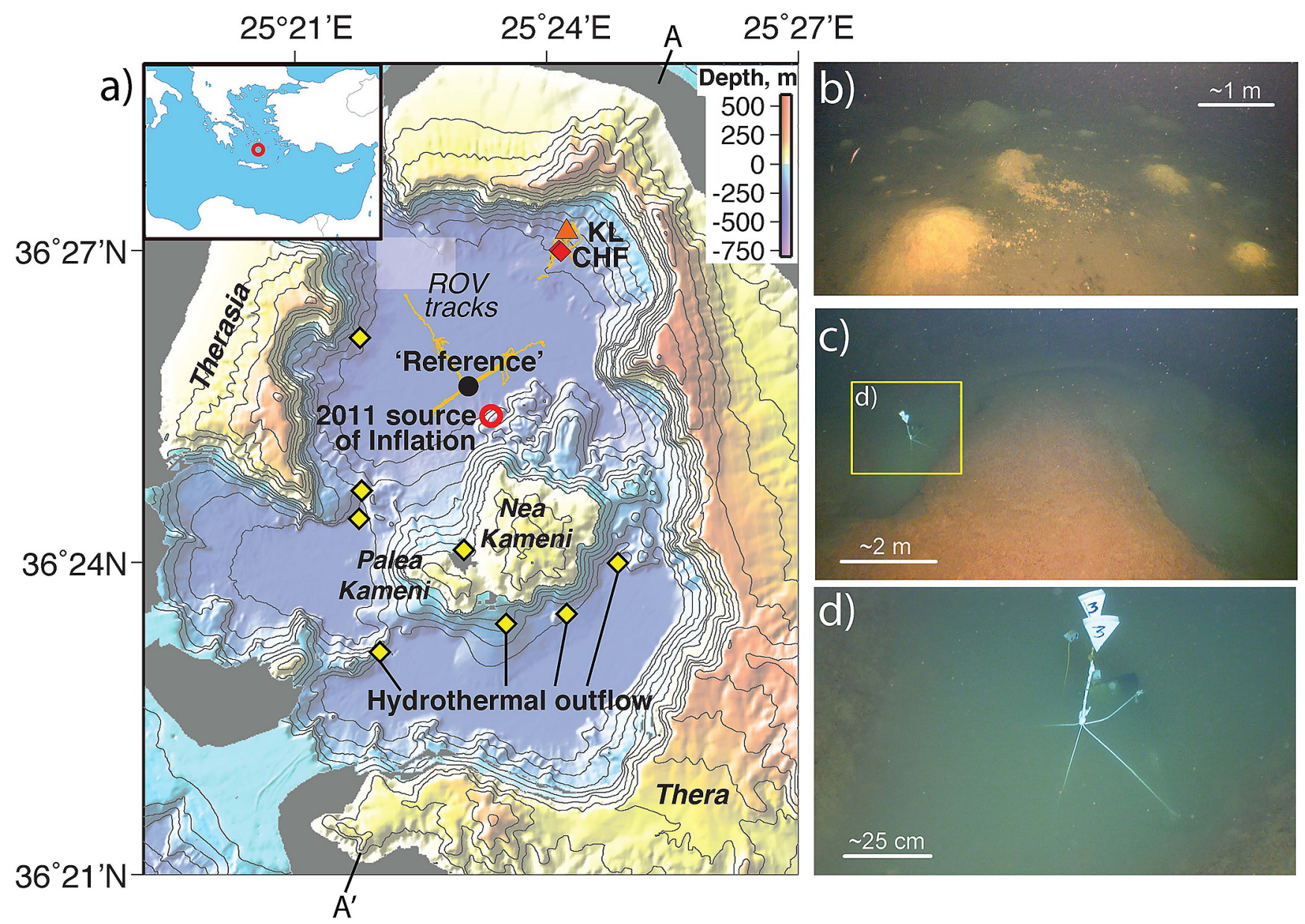

Figure 1 (a) Synthetic topographic map (Nomikou et al., 2014) showing the position of hydrothermal outflow areas within the Santorin caldera. Two samples were collected at the 'Reference' site, which corresponds to near-bottom water away from hydrothermal sources and at the bottom of the northern basin of the caldera. The other samples were collected at the caldera hydrothermal field (CHF), which shows mounds of bacterial mat (b), and at the Kallisti Limnes (KL), which shows sub-sea pools with $\mathrm{CO}_{2}$-rich fluids (Camilli et al., 2015) (c and d). CHF and other hydrothermal areas throughout the caldera where observed in 2006 (Sigurdsson et al., 2006). The red open circle corresponds to the Mogi source model associated with the 2011 inflation event (Newman et al., 2012). A and A' indicate the ends of bathymetric profile in Figure 3.

Greece) and the autonomous underwater vehicle (AUV) Girona 500 (U. Girona, Spain). Temperatures within hydrothermal mounds, composed of an accumulation of bacterial fluff, are $\sim 5^{\circ} \mathrm{C}$ higher than those of ambient seawater $\left(\sim 15^{\circ} \mathrm{C}\right)$, suggesting low temperature hydrothermal outflow at very low flux rates. During this cruise, we collected water samples above these mounds to constrain their origin using helium, neon and carbon isotopes, and off-site for reference (Fig. 1). Moreover, during this cruise, $\mathrm{CO}_{2}$-rich pools were discovered and sampled slightly north of this hydrothermal field, at the base of the caldera wall and at shallower depths of 250 to $200 \mathrm{~m}$ (Camilli et al., 2015) (Fig. 1).

\section{Samples}

Fluid samples were acquired with Niskin bottles fitted at the lower part of the ROV and closed by the ROV operators. The ROV also dove into and collected samples within the Kallisti Limnes, and immediately above them. At the caldera floor we recovered samples at $\sim 1 \mathrm{~m}$ or less above different hydrothermal mounds. Upon ROV recovery on-board, water samples were transferred from the Niskin bottles to copper tubes sealed with pinch clamps at both ends. He and $\mathrm{C}$ isotope measurements were performed at IPGP a few months later.

\section{Analytical Procedure and Results}

Noble gases were extracted from water samples (standards and samples) using the analytical protocol developed by Greau (2012). Distilled water equilibrated with air is used as standard for He and Ne. Helium and neon were measured using the HELIX-SFT (ThermoFisher(C) mass spectrometer sited at IPGP. $\mathrm{CO}_{2}$ concentration and the carbon isotopic ratio were measured at IPGP's Laboratory of Stable Isotopes using their standard procedure (Assayag et al., 2006).

Helium, neon, $\mathrm{CO}_{2}$ abundances, $\mathrm{C} /{ }^{3} \mathrm{He}$ and isotopic ratios are given in Table S-1. Concentrations of ${ }^{4} \mathrm{He}$ vary between $3.8 \times 10^{-8}$ and $2.2 \times 10^{-6} \mathrm{~cm}^{3} \mathrm{STP} / g \mathrm{H}_{2} \mathrm{O}$. The ${ }^{3} \mathrm{He} /{ }^{4} \mathrm{He}$ ratio varies between $0.99 \pm 0.04 \mathrm{Ra}$ and $6.5 \pm 0.3 \mathrm{Ra}$. The ${ }^{20} \mathrm{Ne} /{ }^{22} \mathrm{Ne}$ ratios are atmospheric within uncertainty. The ${ }^{3} \mathrm{He} /{ }^{4} \mathrm{He}$ ratio correlates positively with the ${ }^{4} \mathrm{He} /{ }^{22} \mathrm{Ne}$ (Fig. 2) suggesting a mixing between air/seawater and a mantle-derived component. The $\mathrm{CO}_{2} /{ }^{3} \mathrm{He}$ ratio varies from $1.0 \times 10^{10}$ to $9.25 \times 10^{11}$. The carbon isotopic ratios vary from $-0.13 \pm 0.06$ up to $1.06 \pm 0.06 \%$ relative to the PDB standard and are negatively correlated with the ${ }^{3} \mathrm{He} /{ }^{4} \mathrm{He}$ ratios, suggesting also a mixture between two components (Fig. 2). 


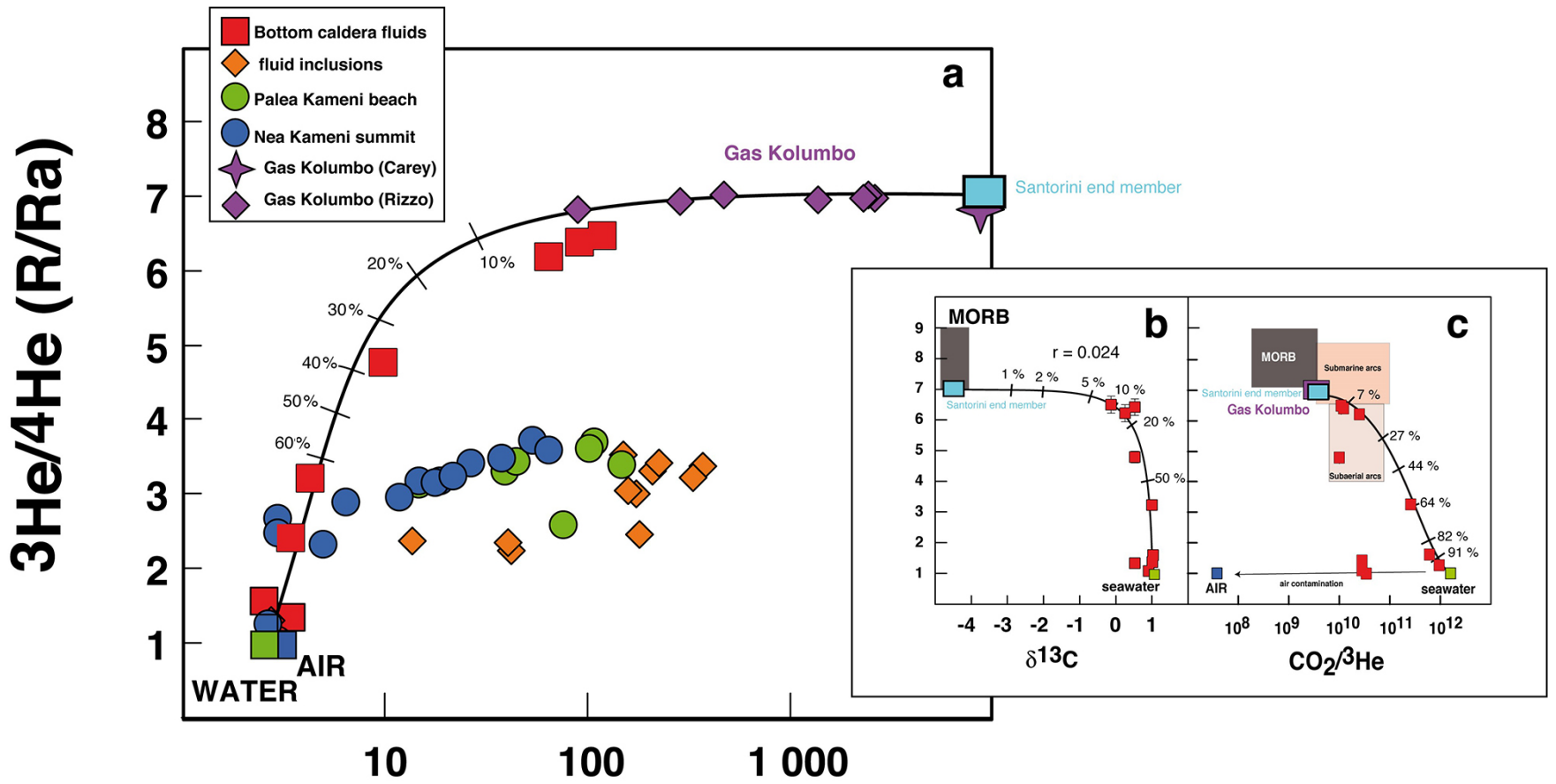

\section{$4 \mathrm{He} / 22 \mathrm{Ne}$}

Figure 2 (a) Mixing diagram showing the ${ }^{3} \mathrm{He} /{ }^{4} \mathrm{He}$ ratio reported against ${ }^{4} \mathrm{He} /{ }^{22} \mathrm{Ne}$ ( $\mathrm{Ra}$ is the helium atmospheric isotopic ratio). The mantle-derived end member has a ${ }^{3} \mathrm{He} /{ }^{4} \mathrm{He}$ ratio of $\sim 7 \mathrm{Ra}$, identical to the value of the nearby Kolumbo volcano (Carey et al., 2013; Rizzo et al., 2016) suggesting a common mantle source. All samples from Palea or Nea Kameni (gases and fluid/melt inclusions in phenocrysts) show a different trend, with a lower ${ }^{3} \mathrm{He} /{ }^{4} \mathrm{He}$ ratio reflecting shallow crustal assimilation (Shimizu et al., 2005; Rizzo et al., 2015). The insert shows the ${ }^{3} \mathrm{He} /{ }^{4} \mathrm{He}$ ratio versus $\delta^{13} \mathrm{C}$ (b) and $\mathrm{CO}_{2} /{ }^{3} \mathrm{He}$ (c). The strong hyperbolic curvature of the mixing curve reported in insert (b) reflects the $\left({ }^{4} \mathrm{He} / \mathrm{CO}_{2}\right)_{\text {seawater }} /\left({ }^{4} \mathrm{He} / \mathrm{CO}_{2}\right)$ MORB ratio of $\sim 0.024$, explaining why the $\delta^{13} \mathrm{C}$ does not show a mantle value whereas helium almost does. Percentages that are indicated on the mixing curves represent the fraction of seawater-derived helium.

\section{Discussion}

The He-C systematics clearly show that fluids have a magmatic origin both for the hydrothermal field with bacterial mounds and for the $\mathrm{CO}_{2}$ pools from the Kallisti Limnes area. Indeed, a measured ${ }^{3} \mathrm{He} /{ }^{4} \mathrm{He}$ ratio as high as $6.5 \pm 0.3 \mathrm{Ra}$ is typical of volcanic contexts. Moreover, we can correct this measured ${ }^{3} \mathrm{He} /{ }^{4} \mathrm{He}$ ratio for the seawater-derived helium using neon, assuming it is entirely of atmospheric origin. The corrected ${ }^{3} \mathrm{He} /{ }^{4} \mathrm{He}$ ratio corresponds to the plateau value reached at high ${ }^{4} \mathrm{He} /{ }^{22} \mathrm{Ne}(>1000)$ in Figure 2. It is close to $\sim 7 \mathrm{Ra}$, which is the same ratio measured on $\mathrm{CO}_{2}$-rich gas from Kolumbo submarine volcano (Carey et al., 2013; Rizzo et al., 2016 ). Carbon isotopes and the $\mathrm{CO}_{2} /{ }^{3} \mathrm{He}$ ratios also confirm the mantle origin for the $\mathrm{CO}_{2}$ and helium. The ${ }^{13} \mathrm{C} /{ }^{12} \mathrm{C}-{ }^{3} \mathrm{He} /{ }^{4} \mathrm{He}$ diagram of Figure 2 suggests a binary mixing between seawater and a mantle-derived component, although the $\delta^{13} \mathrm{C}$ is not reaching the mantle value of $\sim-4.5 \%$ o (Javoy and Pineau, 1991).

The helium isotopic ratios measured in our studied samples are less radiogenic than fluids or minerals collected on the active zone of Palea and Nea Kameni islands (Shimizu et al., 2005; Rizzo et al., 2015). The shallow magma chamber beneath the volcanic active centre of Santorini, is probably located at $\sim 3-4 \mathrm{~km}$ depth (Fig. 3) (Parks et al., 2015). The helium isotopic signature of the surface fumaroles or bubbling springs at the islands does not reach the mantle isotopic signature observed in deep hydrothermal field and $\mathrm{CO}_{2}$ pools of the northeast flank of the caldera (Fig. 2). Therefore, the more radiogenic helium isotopic ratios measured on the fumaroles or bubbling springs from Nea Kameni cannot be considered as reflecting the mantle source and the possible presence of recycled sediments in it, revealing instead rather shallow processes of contamination, as also suggested by Rizzo et al. (2016). The value of the helium isotopic ratio of both Santorini and Kolumbo volcanoes ( $7 \mathrm{Ra}$ ) suggests that the source of volatiles is the asthenosphere rather than the subcontinental lithospheric mantle, which presents a more radiogenic helium isotopic ratio of $6.1 \pm 0.9$ than the MORB source (Gautheron and Moreira, 2002).

Although the deep magmatic origin for helium and $\mathrm{CO}_{2}$ in the northeast hydrothermal field is clear, the flux of magmatic gases is low. At Santorini, there is no observed bubbling in this hydrothermal field, while bubbling is abundant and widespread within the nearby Kolumbo submarine volcano, at the north of the crater (Nomikou et al., 2012; Carey et al., 2013; Rizzo et al., 2016). The Santorini hydrothermal mounds also show temperatures that are only $5{ }^{\circ} \mathrm{C}$ above ambient seawater temperature, much lower than the $>100^{\circ} \mathrm{C}$ measured at Kolumbo's hydrothermal outflows. These temperatures and the visual observations of the mounds and $\mathrm{CO}_{2}$ pools, with no visual evidence of flow, indicate that the hydrothermal flux at the Caldera Field is very low. A dilution of the gas flux from the mantle is required before reaching surface. Anomalies of $\mathrm{He}$ and $\mathrm{CO}_{2}$ concentrations were measured on soils onshore along the Kolumbo line (Barberi and Carapezza, 1994). Unfortunately, no isotopic composition was measured to confirm if these gases are the same. However, the location of these anomalous concentrations of $\mathrm{He}$ and $\mathrm{CO}_{2}$ suggests that the mantle-derived gases we observed at the bottom of Santorini caldera extend up to the surface, following the tectonic Kolumbo line, which we therefore infer to be preferential path for degassing. 


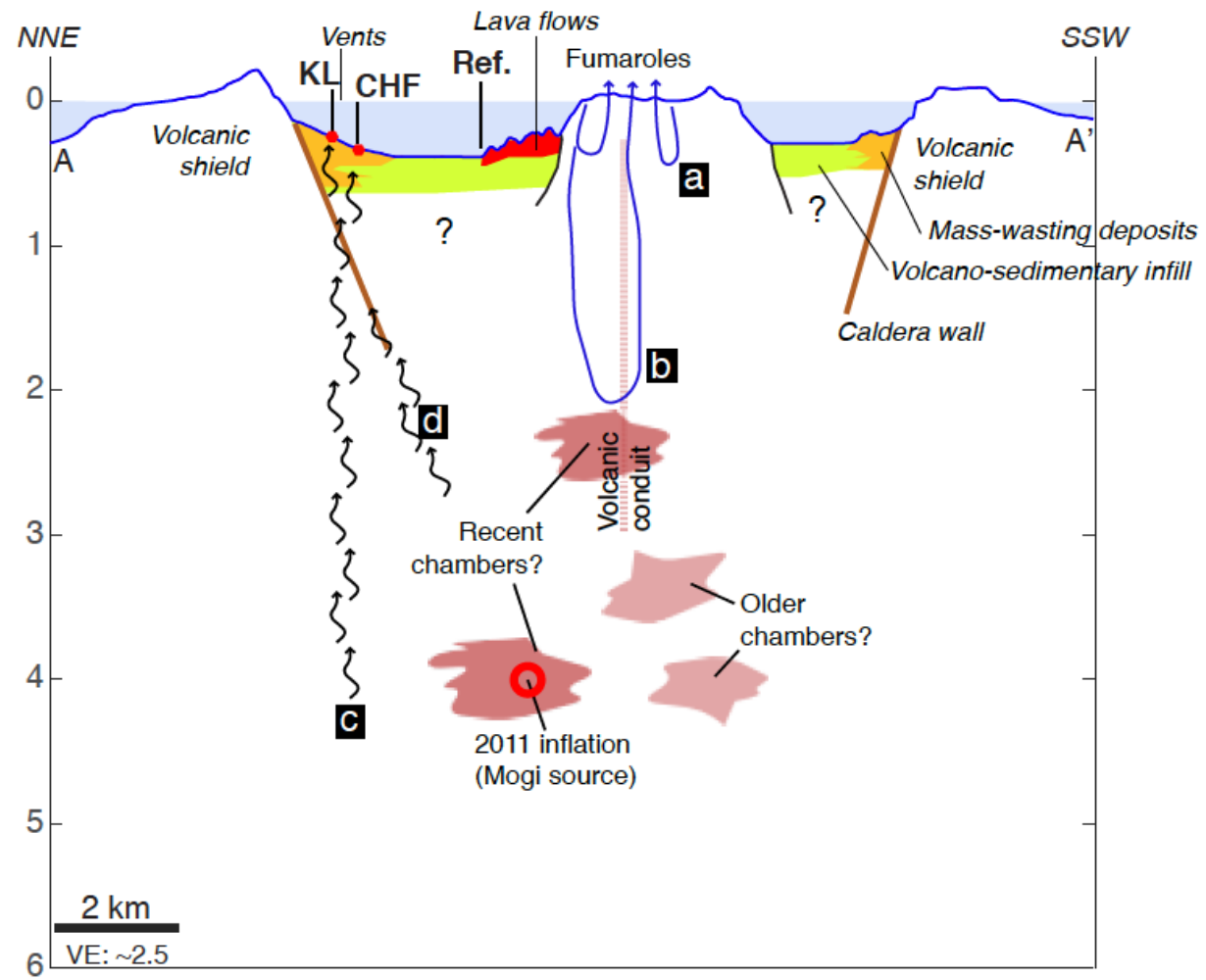

Figure 3 Possible sources and transfer of magmatic $\mathrm{CO}_{2}$ and He within the Santorini caldera. Gases from Nea Kameni derive from a shallow reservoir, which is degassed and has assimilated crustal rocks, sampled by hydrothermal circulation (a, b). A pristine mantle signature is sampled by fluids at the Kalisti Limnes and hydrothermal areas. These fluids may either percolate through the volcanic shield and the pre-volcanic basement (c), or be supplied from a more central area and in association with recent magma chambers, if the fluids migrate along caldera walls and associated caldera faults (d).

Figure 3 summarises our vision of the different degassing processes occurring within Santorini caldera. Magmatic gases from the shallow magmatic chamber degas below Nea and Palea Kameni thanks to hydrothermal circulation, although their compositions do not reflect the mantle source. Crustal assimilation has altered these deep-seated signatures and, notwithstanding recent magma injections, the helium isotopic composition is not representative of the mantle source. A flux of magmatic $\mathrm{CO}_{2}$ and helium is observed on the NE of the caldera, on the Kalisti Limnes and on caldera hydrothermal areas, with mantle compositions. However, the gas likely focuses along the tectonic Kolumbo line, with a very weak flux and diluted with seawater. A detailed work on the geometry, extent, and thermal structure of these vents is required to estimate this magmatic gas flux better. The helium isotopic signature is similar to the one of the Kolumbo volcano (Carey et al., 2013; Rizzo et al., 2016), suggesting that those two volcanoes either sample the same magmatic source for volatiles, or there are two different sources that are geochemically similar for volatiles, although they might be different for other elements (Klaver et al., 2016). Moreover, this source appears similar to the MORB source instead of being the subcontinental mantle, which presents a more radiogenic helium isotopic signature (Gautheron and Moreira, 2002).

\section{Conclusions}

Using new helium and $\mathrm{CO}_{2}$ in water collected at the bottom of the Santorini caldera, at recently discovered hydrothermal fields and nearby $\mathrm{CO}_{2}$-rich pools (Kallisti Limnes), we show that $\mathrm{C}$ and $\mathrm{He}$ at Santorini are mantle-derived and that the magma source of these volatiles is similar to that of the nearby
Kolumbo submarine volcano. The fluids from the submarine hydrothermal field derive directly from the deep magmatic system of Santorini without being affected by the shallow magmatic plumbing as for Nea and Palea Kameni islands. These fluids follow efficient paths to the seafloor likely along fault zones anchored deep in the volcanic arc. The helium isotopic composition show that the mantle source of the Santorini magmatism is more likely the asthenosphere than the subcontinental lithospheric mantle.

\section{Acknowledgements}

We thank the crew of the R/V AEGEO and the pilots of the ROV Max Rover. C. Chaduteau is thanked for the carbon analyses. Ship time was provided by the Eurofleets CALDERA 2012 Project (EU) and by HCMR (Greece). JE and CM were also partly supported by the DCO initiative from the Alfred Sloan Foundation. MM thanks the region Ile de France (SESAME) for the funding of the Helix-SFT. This is IPGP contribution number 4040

Editors: Helen Williams, Maud Boyet

\section{Additional Information}

Supplementary Information accompanies this letter at http:// www.geochemicalperspectivesletters.org/article1914.

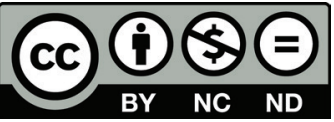

This work is distributed under the Creative Commons Attribution Non-Commercial No-Derivatives 4.0 License, which permits 
unrestricted distribution provided the original author and source are credited. The material may not be adapted (remixed, transformed or built upon) or used for commercial purposes without written permission from the author. Additional information is available at http://www.geochemicalperspectivesletters.org/copyright-and-permissions.

Cite this letter as: Moreira, M., Escartin, J., Scelin, L., RuziéHamilton, L., Nomikou, P., Mével, C., Andreani, M. (2019) New insights into the plumbing system of Santorini using helium and carbon isotopes. Geochem. Persp. Let. 10, 46-50.

\section{References}

Assayag, N., Rivé, K., Ader, M., Jézéquel, D., Agrinier, P. (2006) Improved method for isotopic and quantitative analysis of dissolved inorganic carbon in natural water samples. Rapid Communications in Mass Spectrometry 20, 2243-2251.

BArberi, F., CARAPezzA, L. (1994) Helium and $\mathrm{CO}_{2}$ soil gas emission from Santorini (Greece). Bulletin of Volcanology 56, 335-342.

Camilli, R., Nomikou, P., Escartin, J., Ridao, P., Mallios, A., Kilias, S., Argyraki, A., Andreani, M., Ballu, V., Campos, R., Deplus, C., Gabsi, T., Garcia, R., Gracias, N., Hurtos, N., Magi, L., Mevel, C., Moreira, M., Palomeras, N., Pot, O., Ribas, D., Ruzie, L., SAKellariou, D. (2015) The Kallisti Limnes, carbon dioxide-accumulating subsea pools. Scientific Reports 12152.

Carey, S., Nomikou, P., Croff Bell, K., Lilley, M., Lupton, J.E., Roman, C., Stathopoulou, E., Bejelou, K., Ballard, R. (2013) $\mathrm{CO}_{2}$ degassing from hydrothermal vents at Kolumbo submarine volcano, Greece, and the accumulation of acidic crater water. Geology 41, 1035-1038.

Friedrich, W.L., Kromer, B., Friedrich, M., Heinemeier, J., Pfeiffer, T., TALAMO, S. (2006) Santorini Eruption Radiocarbon Dated to 16271600 B.C. Science 312, 548

Gautheron, C., Moreira, M. (2002) Helium signature of the subcontinental lithospheric mantle. Earth and Planetary Science Letters 199, 39-47.

GREAU, C. (2012) Apport des gaz rares au suivi hydrogéochimique d'un stockage de $\mathrm{CO}_{2}$ - Application à un analogue naturel de fuites. Thesis University Paris VII.

JavoY, M., PINEAU, F. (1991) The volatiles record of a "popping" rock from the Mid-Atlantic Ridge at $14^{\circ} \mathrm{N}$ : chemical and isotopic composition of gas trapped in the vesicles. Earth and Planetary Science Letters 107, 598-611.

Klaver, M., Carey, S., Nomikou, P., Smet, I., Godelitsas, A., Vroon, P.Z. (2016) A distinct source and differentiation history for Kolumbo submarine volcano, Santorini volcanic field, Aegean arc. Geochemistry, Geophysics, Geosystems 17, 3254-3273.

Newman, A.V., Stiros, S., Feng, L., Psimoulis, P., Moschas, F., SaltoGianni, V., Jiang, Y., Papazachos, C., Panagiotopoulos, D., Karagianni, E., VAmVAKaris, D. (2012) Recent geodetic unrest at Santorini Caldera, Greece. Geophysical Research Letters 39, L06309.

Nomikou, P., Carey, S., Papanikolaou, D., Croff Bell, K., SaKelLariou, D., Alexandri, M., Bejelou, K. (2012) Submarine volcanoes of the Kolumbo volcanic zone NE of Santorini Caldera, Greece. Global and Planetary Change 90-91, 135-151.

Nomikou, P., Papanikolaou, D., Alexandri, M., Sakellariou , D., RoUSAKIS, G. (2013) Submarine volcanoes along the Aegean volcanic arc. Tectonophysics 597-598, 123-146.

Nomikou, P., Parks, M.M., Papanikolaou, D., Pyle, D.M., Mather, T.A., Carey, S., Watts, A.B., Paulatto, M., Kalnins, M.L., Livanos, I., Bejelou, K., Simou, E., Perrose, I. (2014) The emergence and growth of a submarine volcano: The Kameni islands, Santorini (Greece). GeoResJ 1-2, 8-18

Parks, M., Caliro, S., Chiodini, G., Pyle, D.M., Mather, T.A., Berlo, K., Edmonds, M., Biggs, J., Nomikou, P., Raptakis, C. (2013) Distinguishing contributions to diffuse $\mathrm{CO}_{2}$ emissions in volcanic areas from magmatic degassing and thermal decarbonation using soil gas ${ }^{222} \mathrm{Rn}-\delta^{13} \mathrm{C}$ systematics: Application to Santorini volcano, Greece. Earth and Planetary Science Letters 377-378, 180-190.

Parks, M.M., MoOre, J.D.P., PAPAnikolaou, X., Biggs, J., Mather, T.A., Pyle, D.M., Raptakis, C., PARAdissis, D., HoOPer, A., PARSOnS, B., NomiKOU, P. (2015) From quiescence to unrest: 20years of satellite geodetic measurements at Santorini volcano, Greece. Journal of Geophysical Research Solid Earth 120, 1309-1328.
Rizzo, A., Barberi, F., Carapezza, L., Di Piazza, A., Francalanci, L., SORTINO, F., D'AlESSANDRO, W. (2015) New mafic magma refilling a quiescent volcano: Evidence from $\mathrm{He}-\mathrm{Ne}-\mathrm{Ar}$ isotopes during the 20112012 unrest at Santorini, Greece. Geochemistry, Geophysics, Geosystems 16, 798-814

Rizzo, A., Caracausi, A., Chavagnac, V., Nomikou, P., Polymenakou, P., Mandalakis, M., Kotoulas, G., Magoulas, A., Castillo, A., LAMPRIDOU, D. (2016) Kolumbo submarine volcano (Greece) An active window into the Aegean subduction system. Scientific Reports $6,1-9$.

Shimizu, A., Sumino, H., Nagao, K., Notsu, K., Mitropoulos, P. (2005) Variation in noble gas isotopic composition of gas samples from the Aegean arc, Greece. Journal of Volcanology and Geothermal Research 140, 321-339.

Sigurdsson, H., Carey, S., Alexandri, M., Vougioukalakis, G., Croff, K., Roman, C., Sakellariou, D., Anagnostou, C., Rousakis, G., Ioakim, C., Godou, A., Ballas, D., Misaridis, T., NomikoU, P. (2006) Marine Investigations of Greece's Santorini Volcanic Field. EOS 87, 337. 